\title{
Environmental and climatic impact on the infection and mortality of SARS-CoV-2 in Peru
}

\author{
Victor J. Samillan ${ }^{1 \#}$ Diana Flores $^{2}$ Eduardo Rojas $^{3}$ Brian R. Zutta $^{4 \#}$ \\ Affiliations: \\ ${ }^{1}$ Universidad Le Cordon Bleu, Lima Perú, \\ ${ }^{2}$ Instituto Nacional de Salud, Lima Perú. \\ ${ }^{3}$ School of Geography and History, University of Barcelona, Barcelona, Spain, \\ ${ }^{4}$ Green Blue Solutions, Lima. \\ \# These authors contributed equallity
}

Correspondence: Víctor J. Samillán victor.samillan@ulcb.edu.pe

\begin{abstract}
The role of the environment and climate in the transmission and case-fatality rates of SARSCoV-2 is still being investigated. Elevation and air quality are believed to be significant factors in the current development of the pandemic, but the influence of additional environmental factors remain unclear.

In this study, we explored the relationship between the cumulative number of infections and mortality cases with climate (temperature, precipitation, solar radiation, water vapor pressure, wind), environmental data (elevation, NDVI, $\mathrm{PM}_{2.5}$ and $\mathrm{NO}_{2}$ concentration), and population density in Peru. Using the data from confirmed cases of infection from 1287 districts and confirmed cases of mortality in 479 districts, we used Spearman's correlations to assess the correlation between environmental and climatic factors with cumulative infection cases, cumulative mortality and case-fatality rate. We also explored district cases by the ecozones of coast, sierra, high montane forest and lowland rainforest.

Multiple linear regression models indicate elevation, mean solar radiation, air quality, population density and green cover are influential factors in the distribution of infection and mortality of SARS-CoV-2 in Peru. Case-fatality rate was weakly associated with elevation. Our results also strongly suggest that exposure to poor air quality is a significant factor in the mortality of individuals with SARS-CoV-2 below the age of 30 .
\end{abstract}

We conclude that environmental and climatic factors do play a significant role in the transmission and case-fatality rates in Peru, however further study is required to see if these relationships are maintained over time.

\section{Introduction}

As SARS-CoV-2 has spread around the world in a few months, several groups of investigators have started to look into the different factors that could be related to the distribution of the infection and the severity of the disease. The incidence of infection in different countries and cities suggests that several factors influence the rate of infection, which are not only related to the virus and the immune system. In the case of Peru, the cities that have the most cases are generally located near the coast and have poor air quality throughout the year (https://www.datosabiertos.gob.pe/). In addition, population density seems to be a key factor in the spread of the virus, where overcrowded cities increase the probability of contact with infected individuals, increasing the number of infection and mortality cases in a short amount of time. Therefore, population density should be taken into account when analyzing different cofactors SARS-CoV-2 distribution. 
Although more studies are necessary, the rate of infection and the severity of the diseases seems different for people living in cities at high altitudes, where not only hipoxia is a major factor, but other factors such as air quality, solar radiation, and population density, could play a role in SARS-CoV-2 person-to-person transmission. Arias-Reyes et al. (2020) suggested that there exists less rate of infection at high altitude possibly due to a lower level of expression of ACE2 compared to sea level. This observation is important, particularly since SARS-CoV-2 uses ACE2 as a point of infection for the cells (Ren et al., 2020). Yao et al. (2020) explored the rate of SARS-CoV-2 infection across China, and concluded that there was no correlation between temperature, UV and the rate of infection. However, they recommended future studies using more complex models and environmental factors. Finch et al., (2016) explored the role of pollution exposure in the development of different diseases, where heart and respiratory diseases indicated a detrimental role of pollution on the endothelial integrity, and the changes in the levels of Endothelin I could be observed in people that were exposed to air pollution.(Briet et al. 2007 )

Environmentals factors related to mechanics of different virus spread have been studied by several groups, before the pandemic. Pica et al. (2012) studied the environmental factors related to the spread of seasonal influenza and concluded that some meteorological factors play a central role in the person-to-person transmission of the virus, besides the sociodemographic factors. It is well known that UV radiation can decontaminate surfaces and air, and UV incidence increases at higher elevations and cities will have different exposures depending on their location. Kowalsky et al. (2009) demonstrated that the UV light can destroy a bacteries, many viruses and fungi, but additional studies are necessary to understand the impact of UV on SARS-CoV-2 in the natural environment.

Understanding all the factors that are related to the spread of SARS-CoV-2 will be an important part of public policy, particularly towards the implementation of focalized quarantines in cities and districts where the cases of infection are high. Therefore, this study aims to explore the different cofactors that could increase or decrease the possibility of person-to-person transmission of SARS-CoV-2. The main objectives of this study was to explore the relationship between SARS-CoV-2 infection and mortality cases, case-fatality rates with a set of climate (temperature, precipitation, solar radiation, water vapor pressure, and wind), environmental data (elevation, NDVI, $\mathrm{PM}_{2.5}$ and $\mathrm{NO}_{2}$ concentration), and population density in Peru. We also divide the distribution of infection, mortality and case-fatality rates by four ecozones (coast, sierra, high montane forest and lowland rainforest) and subset mortality cases by age groups and gender.

\section{Methods}

We obtained SARS CoV 2 confirmed cases by district, of the 1873 districts in Peru, from official reports provided by the Peruvian Ministry of Health (MINSA), through an official government open data portal (https://www.datosabiertos.gob.pe/). We used the cumulative number of confirmed cases of infection from 1287 districts and confirmed cases of mortality in 479 districts, where at least 1 confirmed case was registered as of June 27, 2020 (Figure 1). The first case of SARS CoV 2 was registered on March 5, 2020. Under this criteria, the number of positive SARS CoV 2 cases analyzed were 263,743 and 7,877 deaths by June 27, 2020. Available data of infection included date of confirmation, while data on mortality included age, sex, and date registered. The first confirmed case of SARS CoV 2 in Peru was on March 6, 2020. Infection and mortality values were log-transformed to meet statistical assumptions in relation to residuals and added 1 to avoid taking the logarithm of 0 (Liu et al, 2020; Xie and Zhu, 2020; Zhu et al., 2020). 
We also assessed case-fatality rates, which implies the severity of the condition by estimating the proportion of cases that die of a given condition (Segovia-Juarez et al., 2020). The casefatality rate was estimated by dividing the number of cause-specific deaths among the incidence cases by the total number of incident cases*100 (CDC, 2019)

We labeled districts based on four ecozones, including coast, sierra, high montane forest and lowland rainforest, which was originally developed based on elevation and biogeography and used in national and international reporting, and have a significant effect on agricultural activity, population density, population connectivity and other socioeconomic activities (MINAM, 2016).

\section{Climate and environmental data}

A set of climate metrics were obtained from WorldClim version 2.1 (Fick \& Hijmans, 2017), which presents a historical baseline from the years 1979 to 2000 and includes monthly temperature, rainfall, wind speed, and solar radiation. Satellite-based environmental data was obtained from a variety of satellite sensors that detect environmental variables, including elevation, vegetation cover, and air quality. Vegetation cover was estimated through NDVI (Normalized Difference Vegetation Index), a commonly used spectral index used to quantify green cover, including agricultural extent, forest cover, and green cover in urban settings. We infer air quality through the metrics of two health-relevant air pollutants, which include particulate matter at $2.5 \mu \mathrm{m}\left(\mathrm{PM}_{2.5}\right)$ and nitrogen dioxide $\left(\mathrm{NO}_{2}\right)$. Population density was obtained from the WorldPop model of population density $\left(\right.$ people $\mathrm{km}^{-2}$ ) for Peru adjusted to match official United Nations population estimates for the year 2020 (www.worldpop.org). Further details on climate data and satellite-based environmental data are provided in the online supplementary material.

\section{Data analysis}

We extracted the zonal statistics by district (i.e. average value per district polygon) of each of the climate, remotely sensed and population density layers using ArcPro (verison 2.2). We used SPSS 25.0 (IBM, USA) for all statistical analysis of the extracted values. We used the onesample Kolmogorov-Smirnov parametric test to evaluate the distribution of residuals obtained for each district from each of the original 36 data layers used. Covariance within the subsets of climate and environmental variables were estimated with Spearman's Rho correlation, where correlation of the order of 0.9 or larger were determined to have a high covariance. As a result, the final reduced data set used in this study were 21 data layers, including 14 climatic layers, 6 environmental layers and the population density model (Table 1). The climatic layers included 4 temperature, 4 rainfall, 2 solar radiation, 2 wind speed and 2 water vapor metrics. All 6 environmental layers and the population density model had a relatively low level of covariance and were kept for further analysis. The climate and environmental data were also normalized (following Zhu et al., 2020), due to the different units used in each variable, through the following method:

$$
X=X_{n}-X_{a n} / S_{n}
$$

Where $X$ is the normalized data, $X_{n}$ is the raw data for the variable, $X_{a n}$ is the mean value of the raw data, and $S_{\mathrm{n}}$ is the standard deviation of $X_{n}$.

We used stepwise linear regression to explore the association of climatic and environmental variables with the log-transformed data of cumulative number of confirmed cases of infection and confirmed cases of mortality, across Peru and within ecozones. The number of cases were used as dependent variables, and the environmental and climatic were selected as independent variables. The resulting statistically significant predictive models use one or multiple variables that best explain the dependent variable. The adjusted $\mathrm{R}^{2}$ from model fitting indicates the 
percentage of all factors that explain the distribution of cases and the magnitude of the standardized $\beta$ reflects the influence of the corresponding variable in the predictive model. Collinearity diagnostics, resulting from the regression, were also used to identify model variables that were highly correlated. Significant differences between means were evaluated using one-way ANOVA followed by a Tukey test.

\section{Results}

The district of San Juan de Lurigancho, of the department of Lima and in the coastal ecozone, had the most number of confirmed infected cases and case fatalities of SARS-CoV-2, with 13,724 total infections and 394 fatalities, up until the date of the data obtained for this study. The average number of confirmed cases of infection and fatalities was 205 (SD \pm 938 ) and 16.4 ( $\mathrm{SD} \pm 42.2$ ) per district, respectively. Across ecozones, the number of registered male fatalities was 5,601 (71.1\%) and females was 2,276 (28.9\%). The average age of total male fatalities was $64.2(\mathrm{SD} \pm 15.6)$ and females was $66.3(\mathrm{SD} \pm 15.9)$. There was also a significant difference between ecozones for mean age of fatalities $(F=5.64, p<0.001)$ and female only cases $(F=$ $6.03, p<0.001)$, but not in male only cases $(F=1.46, p=0.224)$. We found no significant difference between the mean case-fatality rates by ecozones $(F=0.34, p=0.80$; Table 2$)$.

Correlation analysis indicated a positive correlation of total infections with $\mathrm{PM}_{2.5}(\square=0.449)$ and a negative correlation with elevation $(\square=-0.476)$, where the number of infections correlates with increased air pollution, while there are less number of infections with elevation Figure 2). Similarly, correlation analysis indicated a high positive correlation coefficient between mean tropospheric $\mathrm{NO}_{2}(\square=0.497, \mathrm{p}<0.001), \mathrm{PM}_{2.5}(\square=0.506 ; \mathrm{p}<0.001)$ and registered mortality across sexes and in the male population with $\square=0.504$ and $\square=0.486$, respectively.

In stepwise linear regression model fitting, the three most important parameters that explain the distribution of cumulative number of infections across the country $\left(R^{2}=0.46 ; p\right.$-value $\left.=0.038\right)$ were NDVI $(\beta=-0.392)$, elevation $(\beta=-0.311)$, and mean solar radiation $(\beta=-0.244)$ (Table $3)$. The negative correlation indicates a decrease in the cumulative number of infections, with an increase in surrounding green cover (NDVI). In addition, the cumulative number of infections decreases with increasing elevation and increasing mean solar radiation. Within each ecozone, parameters importance change indicating the importance of population density $(\beta=0.474)$ in the coast, NDVI $(\beta=-0.359)$ in the sierra, maximum $\mathrm{NO}_{2}(\beta=0.352)$ in high montane forest, and elevation $(\beta=-0.441)$ in lowland rainforest.

Model fitting for cumulative mortality cases across the Peru indicated the negative correlation of NDVI $(\beta=-0.299)$, elevation $(\beta=-0.245)$, and mean solar radiation $(\beta=-0.230)$, and the positive correlation with mean $\mathrm{NO}_{2}(\beta=0.237)$ and population density $(\beta=0.215)$ (Table 4$)$. Population density was the most influential factor for mortality in the coastal ecozone, lowland rainforest, and male and female mortality across the country. It is worth noting that adjusted $\mathrm{R}^{2}$ indicated that the models included at least $28 \%$ of the factors that affect the difference in mortality.

Regarding age groups, mean $\mathrm{NO}_{2}$ was the most influential factor of difference of mortality for individuals with an age range of 0 to $17(\beta=0.654)$ and 18 to $29(\beta=0.422)$ (Table 5). Population density was the most influential factor for the remaining age ranges of 30 to 49 ( $\beta=$ $0.306), 50$ to $70(\beta=0.483)$, and above $80(\beta=0.309)$. However, it is worth noting that mean $\mathrm{NO}_{2}$ was indicated as an influential factor for mortality for the age ranges of 30 to 49 ( $\beta=$ $0.236)$ and above $80(\beta=0.258)$.

A positive correlation from model fitting was found between case fatality rates and elevation ( $\beta$ $=0.318)$, although a relatively low explanatory factor $\left(\mathrm{R}^{2}=0.12 ; \mathrm{p}\right.$-value $\left.=0.015\right)$ compared to most predictive models performed in this study (Table 6). Indeed, case fatality rate models had 
the lowest $\mathrm{R}^{2}$, although statistically significant $(\mathrm{p}<0.05)$, compared to models for infection and mortality. Elevation was the most influential factor for the coast $(\beta=0.281)$, sierra $(\beta=0.303)$, and high montane forest $(\beta=0.466)$. Mean diurnal range was the main factor for case fatality rates in high montane forests $(\beta=0.466)$ and the only climate variable to appear as a factor for model fitting in this study.

\section{Discussion}

Our study found that several environmental factors are influential in the cumulative number of SARS-CoV-2 infection and mortality, with particular factors having apparently significant roles in specific scenarios. Generally, the cumulative number of infections is reduced with increased elevation and solar radiation, but other factors such as poor air quality and population density have significant roles. Surprisingly, NDVI, as a measure of green cover and socioeconomic level in urban settings, was a strong predictive factor of SARS-CoV-2 infection (Table 3). Previous studies have found that more affluent suburbs in Peru tend to be less populated, have more green space that reflects higher property values (Duarte-Garcia et al., 2018), and therefore, residents may be more likely to have access to private health measures that could decrease rates of infection in the longer term.

Once we separate infection and mortality by ecozones, the influence of environmental factors is similar to looking at Peru as a whole, with a few notable exceptions. Solar radiation is a much more influential factor in the Sierra, where there are strong geographic patterns particularly in the south, and UV radiation is known to be strong in these drier environments (Figure 2). If we take into account the UV radiation as a possible factor that could decrease the survival of the virus in the air, this could account for the decrease of infected people in the sierra and in the south of the country.

Mean $\mathrm{NO}_{2}$ concentration is an overriding factor for the cumulative number of mortality for ages below 30. Higher mean $\mathrm{NO}_{2}$ concentration is indicative of anthropogenic activity, such as fossil fuel consumption and biomass burning, which occur in more population dense districts, but it is only moderately correlated with population density in Peru. Mean $\mathrm{NO}_{2}$ concentration in 2019 was highest in the metropolitan cities of Lima, Arequipa and the small southern city of Moquegua, where $\mathrm{NO}_{2}$ density of above $250 \mu \mathrm{mol} \mathrm{m}{ }^{-2}$ were found year round. Seasonal high concentrations, due to agricultural and other biomass burning, are found in cities in the Amazon basin during the dry season. The overall detrimental effects of air pollution on the health and mortality within populations, in accordance to type and length of exposure is known (Carey et al, 2013), along with other studies exploring its effects on the current pandemic (Fattorini and Regoli, 2020).

Unlike male mortality, we found a significant difference in the mean age of women who died across ecozones in Peru, with a higher average age for women in the Sierra. To our knowledge, this is the first study to indicate the multiple factors that seem to influence female mortality, including a negative correlation with elevation and mean solar radiation, but a larger positive correlation with population density, NDVI and mean $\mathrm{NO}_{2}$ density. Female mortality from SARS-CoV-2 is lower than males in all the countries possibly due to the expression of the ACE2 (angiotensin $\square$ converting enzyme 2) receptor regulated by female hormones. However, protection is lost in older women, as the levels of hormones decrease. The probability of infection in older women becomes similar to their male counterpart, but there is still a higher rate of fatalities in men than women independent of age (Jin Jiam-Min et al, 2020).

Our study also found elevation to be an influential factor in case fatality rate for the coast, sierra, high montane forest, lowland rainforest, and the country as a whole when looking at the data at the district level. This is contrary to the findings Segovvia-Juarez et al. (2020), which studied cases at the provincial level, instead of the district level, and found that the case fatality rate was not modified by elevation. Our analysis indicates a rather weak but statistically 
significant correlation. However, we acknowledge that further studies still need to be conducted to see if this relationship continues throughout the course of the pandemic.

The limitations of this study are indicative of the asymptomatic nature of SARS-CoV-2 for many patients. It is currently unclear the magnitude of underestimation occurring at the present time and accurate numbers may not become available until widespread molecular testing is performed. Also, news reports indicate that the cumulative number of mortality may also be significantly underestimated due to the lack of testing and patient care in overwhelmed urban and rural hospitals, particularly during the peaks of SARS-CoV-2 infection.

In conclusion, elevation is one of several factors that has determined the number of infections and mortality. Other significant factors include population density, air quality, solar radiation and NDVI, as a measure of both green cover and socioeconomic level. Poor air quality was the single most important factor to determine mortality below the age of 30 . We also found that case fatality rate is modified, albeit weakly, by elevation, which is contrary to previously published findings. As more data becomes available, this study can be replicated to see if the relationship between SARS-CoV-2 and climatic and environmental factors are maintained over time.

\section{Acknowledgement}

The authors wish to thank Professor Dr. Michal Horowitz for her critical reading and discussion of the manuscript.

\section{References}

Christian Arias-Reyes, NataliaZubieta-DeUrioste, Liliana Poma-Machicao, Fernanda AliagaRaduan, Favio Carvajal-Rodriguez, MathiasDutschmann, Edith M.Schneider-Gasser, GustavoZubieta-Callejab, JorgeSolizab Does the pathogenesis of SARS-CoV-2 virus decrease at high-altitude? Respiratory Physiology \& Neurobiology Volume 277, June 2020, 103443

Briet M, Collin C, Laurent S, Tan A, Azizi M, Agharazii M, Jeunemaitre X, Alhenc $\square$ Gelas F, Boutouyrie P. Endothelial function and chronic exposure to air pollution in normal male subjects. Hypertension. 2007; 50:970-976.

Carey IM, Atkinson RW, Kent AJ, et al. Mortality associations with long-term exposure to outdoor air pollution in a national English cohort. Am J Respir Crit Care Med 2013;187:122633 .

Finch, J., \& Conklin, D. J. Air Pollution-Induced Vascular Dysfunction: Potential Role of Endothelin-1 (ET-1) System. Cardiovascular toxicology, 2016, 16(3), 260-275.

Fattorini D, Regoli F. Role of the chronic air pollution levels in the COVID-19 outbreak risk in Italy. Environmental Pollution. 2020; 264: 114732.

Fick, S.E. and R.J. Hijmans. WorldClim 2: new $1 \mathrm{~km}$ spatial resolution climate surfaces for global land areas. International Journal of Climatology , 2017, 37 (12): 4302-4315.

[dataset]. Plataforma Nacional de Datos Abiertos. [Internet]. PERÚ; 2020.

Disponible en: https://www.datosabiertos.gob.pe/search/field_topic/covid-19-

917?sort_by=changed

Jin Jian-Min, Bai Peng, He Wei, Wu Fei, Liu Xiao-Fang, Han De-Min, Liu Shi, Yang Jin-Kui 
Gender Differences in Patients With COVID-19: Focus on Severity and Mortality. Frontiers in Public Health. Vol 8, April 2020. 152

Kowalski WJ.. Ultraviolet Germicidal Irradiation Handbook: UVGI for Air and Surface Disinfection. 2009, (Springer, New York).

Loret de Mola, U.; Ladd, B.; Duarte, S.; Borchard, N.; Anaya La Rosa, R.; Zutta, B. On the Use of Hedonic Price Indices to Understand Ecosystem Service Provision from Urban Green Space in Five Latin American Megacities. Forests 2017, 8, 478.

L.L. Ren, Y.M. Wang, Z.Q. Wu, Z.C. Xiang, L. Guo, T. Xu, Y.Z. Jiang, Y. Xiong, Y.J. Li, X.W. Li, H. Li, G.H. Fan, X.Y. Gu, Y. Xiao, H. Gao, J.Y. Xu, F. Yang, X.M. Wang, C. Wu, L. Chen, Y.W. Liu, B. Liu, J. Yang, X.R. Wang, J. Dong, L. Li, C.L. Huang, J.P. Zhao, Y. Hu, Z.S. Cheng, L.L. Liu, Z.H. Qian, C. Qin, Q. Jin, B. Cao, J.W. Wang. Identification of a novel coronavirus causing severe pneumonia in human: a descriptive study. Chin. Med. J. (Engl.) (2020),

Pica N, Bouvier NM. Environmental factors affecting the transmission of respiratory viruses. Curr Opin Virol. 2012 Feb;2(1):90-5. doi: 10.1016/j.coviro.2011.12.003. Epub 2012 Jan 4.

Segovia-Juarez, J., JM Castagnetto, GF Gonzales (2020) High altitude reduces infection rate of COVID-19 but not case-fatality rate. Respiratory Physiology \& Neurobiology 281: 103494.

Ye Yao, Jinhua Pan, Zhixi Liu, Xia Meng, Weidong Wang, Haidong Kan, Weibing Wang.No association of COVID-19 transmission with temperature or UV radiation in Chinese cities. European Respiratory Journal 2020 55: 2000517

Zhu L, Liu X, Huang H, Avellan-Llaguno RD, Llaguno Lazo MM, Gaggero A, Soto Rifo R, Pati-ño L, Valencia-Avellan M, Diringer B, Huang Q, Zhu Y-G. Meteorological impact on the COVID-19 pandemic: A study across eight severely affected regions in South America. Science of the Total Environment 2020; 744: 140881.

Table 1 Description of the variables selected for statistical modeling.

\begin{tabular}{|l|l|l|l|}
\hline Data & Source & $\begin{array}{l}\text { Temporal } \\
\text { resolution }\end{array}$ & $\begin{array}{l}\text { Spatial } \\
\text { resolution }\end{array}$ \\
\hline Climatic variables & & & \\
\hline Annual mean temperature & WorldClim & $1970-2000$ & $1 \mathrm{~km}$ \\
\hline Mean diurnal temperature range & WorldClim & $1970-2000$ & $1 \mathrm{~km}$ \\
\hline Temperature seasonality & WorldClim & $1970-2000$ & $1 \mathrm{~km}$ \\
\hline Temperature annual range & WorldClim & $1970-2000$ & $1 \mathrm{~km}$ \\
\hline Annual precipitation & WorldClim & $1970-2000$ & $1 \mathrm{~km}$ \\
\hline Precipitation of Wettest Month & WorldClim & $1970-2000$ & $1 \mathrm{~km}$ \\
\hline Precipitation seasonality & WorldClim & $1970-2000$ & $1 \mathrm{~km}$ \\
\hline Precipitation of warmest quarter & WorldClim & $1970-2000$ & $1 \mathrm{~km}$ \\
\hline
\end{tabular}


medRxiv preprint doi: https://doi.org/10.1101/2020.09.16.20196170; this version posted September 19, 2020. The copyright holder for this preprint (which was not certified by peer review) is the author/funder, who has granted medRxiv a license to display the preprint in perpetuity.

All rights reserved. No reuse allowed without permission.

\begin{tabular}{|l|l|l|l|}
\hline Solar radiation (mean) & WorldClim & $1970-2000$ & $1 \mathrm{~km}$ \\
\hline Solar radiation (standard deviation) & WorldClim & $1970-2000$ & $1 \mathrm{~km}$ \\
\hline Water vapor pressure (mean) & WorldClim & $1970-2000$ & $1 \mathrm{~km}$ \\
\hline Water vapor pressure (standard deviation) & WorldClim & $1970-2000$ & $1 \mathrm{~km}$ \\
\hline Wind speed (mean) & WorldClim & $1970-2000$ & $1 \mathrm{~km}$ \\
\hline Wind speed (standard deviation) & WorldClim & $1970-2000$ & $1 \mathrm{~km}$ \\
\hline Environmental variables & & & \\
\hline Elevation & SRTM & 2000 & $90 \mathrm{~m}$ \\
\hline NDVI (mean) & MODIS & 2019 & $500 \mathrm{~m}$ \\
\hline PM 2.5 (mean) & MERRA-2 & 2019 & $62 \mathrm{~km}$ \\
\hline Tropospheric $\mathrm{NO}_{2}$ (mean) & Sentinel-5P & 2019 & $500 \mathrm{~m}$ \\
\hline Tropospheric $\mathrm{NO}_{2}$ (maximum) & Sentinel-5P & 2019 & $500 \mathrm{~m}$ \\
\hline Population density & WorldPop & 2020 & $1 \mathrm{~km}$ \\
\hline
\end{tabular}

Table 2 Difference between mean age \pm SE of fatalities in districts within different ecozones. Min-max represents the range of age and $\mathrm{n}$ is the number of cases.

\begin{tabular}{|c|l|l|l|l|l|}
\hline & Ecozone & & & & \\
\hline Cases & Coast & Sierra & $\begin{array}{l}\text { High montane } \\
\text { forest }\end{array}$ & $\begin{array}{l}\text { Lowland } \\
\text { rainforest }\end{array}$ & $\begin{array}{l}\text { 1-way ANOVA } \\
\text {-value }\end{array}$ \\
\hline Cumulative fatalities & $65.1 \pm 0.2$ & $66.5 \pm 0.7$ & $62.3 \pm 1.3$ & $62.8 \pm 0.8$ & $<0.001$ \\
\hline min-max & $0-101$ & $16-97$ & $1-99$ & $2-95$ & \\
\hline $\mathrm{n}$ & 4737 & 423 & 192 & 390 & \\
\hline Male fatalities & $64.4 \pm 0.3$ & $64.7 \pm 0.9$ & $62.5 \pm 1.4$ & $62.8 \pm 1.0$ & 0.224 \\
\hline min-max & $0-101$ & $16-97$ & $1-90$ & $6-95$ & \\
\hline $\mathrm{n}$ & 3091 & 281 & 138 & 274 & \\
\hline Female fatalities & $66.4 \pm 0.4$ & $70.0 \pm 1.2$ & $61.6 \pm 2.7$ & $62.8 \pm 1.6$ & $<0.001$ \\
\hline min-max & $0-100$ & $25-95$ & $1-99$ & $2-92$ & 116 \\
\hline $\mathrm{n}$ & 1646 & 142 & 54 & \\
\hline
\end{tabular}


medRxiv preprint doi: https://doi.org/10.1101/2020.09.16.20196170; this version posted September 19, 2020. The copyright holder for this preprint (which was not certified by peer review) is the author/funder, who has granted medRxiv a license to display the preprint in perpetuity. All rights reserved. No reuse allowed without permission.

Table 3 Predictive models of the relationship of cumulative case infection and environmental and climatic variables.

\begin{tabular}{|l|l|l|l|l|l|}
\hline Dependent & Predictors & Standardized $\beta$ & $\mathrm{R}^{2}$ & Adj. $\mathrm{R}^{2}$ & $p$-value \\
\hline Cumulative inf. & NDVI & -0.392 & 0.46 & 0.46 & 0.04 \\
\hline & Elevation & -0.311 & & & \\
\hline & Radiation mean & -0.244 & & & \\
\hline & $\mathrm{NO}_{2}$ max & 0.171 & & & \\
\hline & $\mathrm{NO}_{2}$ mean & 0.057 & & & \\
\hline & $\mathrm{PM}_{2.5}$ & 0.129 & & & \\
\hline & Pop. density & 0.150 & & & \\
\hline & Wind mean & -0.081 & & & \\
\hline & Radiation (SD) & -0.077 & & & \\
\hline Coast & Pop. density & 0.474 & 0.35 & 0.34 & 0.03 \\
\hline & Elevation & -0.199 & 0 & & \\
\hline & PM2.5 & 0.163 & & & \\
\hline Sierra & NDVI & -0.359 & 0.50 & 0.50 & 0.02 \\
\hline
\end{tabular}




\begin{tabular}{|l|l|l|l|l|l|}
\hline & Radiation mean & -0.272 & & & \\
\hline & Elevation & -0.244 & & & \\
\hline & $\mathrm{NO}_{2}$ mean & 0.191 & & & \\
\hline & $\mathrm{PM}_{2.5}$ & 0.171 & & & \\
\hline & Pop. density & 0.131 & & & \\
\hline & Wind SD & -0.077 & & & \\
\hline $\begin{array}{l}\text { High montane } \\
\text { rainforest }\end{array}$ & $\mathrm{NO}_{2}$ max & 0.325 & 0.40 & 0.39 & $<0.001$ \\
\hline & PM 2.5 & 0.266 & & & \\
\hline & Elevation & -0.253 & & & \\
\hline $\begin{array}{l}\text { Lowland } \\
\text { rainforest }\end{array}$ & Elevation & -0.441 & 0.37 & 0.35 & 0.001 \\
\hline & Pop. density & 0.327 & & & \\
\hline
\end{tabular}

Table 4 Predictive models of the relationship of mortality across and within ecozones and environmental and climatic variables.

\begin{tabular}{|c|c|c|c|c|c|}
\hline & Predictors & Standardized $\beta$ & $\mathrm{R}^{2}$ & Adj. $R^{2}$ & $p$-value \\
\hline \multirow[t]{5}{*}{ Cumulative mortality } & NDVI & -0.299 & 0.48 & 0.48 & $<0.001$ \\
\hline & Elevation & -0.245 & & & \\
\hline & $\mathrm{NO}_{2}$ mean & 0.237 & & & \\
\hline & Radiation mean & -0.230 & & & \\
\hline & Pop. density & 0.215 & & & \\
\hline \multirow[t]{5}{*}{ Male } & Pop. density & 0.250 & 0.46 & 0.45 & $<0.001$ \\
\hline & NDVI & -0.245 & & & \\
\hline & $\mathrm{NO}_{2}$ mean & 0.229 & & & \\
\hline & Elevation & -0.223 & & & \\
\hline & Radiation mean & -0.200 & & & \\
\hline \multirow[t]{3}{*}{ Female } & Pop. density & 0.379 & 0.33 & 0.33 & 0.015 \\
\hline & $\mathrm{NO}_{2}$ mean & 0.191 & & & \\
\hline & Elevation & -0.136 & & & \\
\hline \multirow[t]{2}{*}{ Coast } & Pop. density & 0.502 & 0.37 & 0.36 & $<0.001$ \\
\hline & $\mathrm{PM}_{2.5}$ & 0.335 & & & \\
\hline
\end{tabular}


medRxiv preprint doi: https://doi.org/10.1101/2020.09.16.20196170; this version posted September 19, 2020. The copyright holder for this preprint (which was not certified by peer review) is the author/funder, who has granted medRxiv a license to display the preprint in perpetuity.

All rights reserved. No reuse allowed without permission.

\begin{tabular}{|l|l|l|l|l|l|}
\hline Sierra & Elevation & -0.274 & 0.51 & 0.50 & 0.005 \\
\hline & NDVI & -0.273 & & & \\
\hline & Pop. density & 0.253 & & & \\
\hline & $\mathrm{NO}_{2}$ mean & 0.193 & & & \\
\hline High montane rainforest & $\mathrm{NO}_{2}$ max & 0.576 & & & \\
\hline & $\mathrm{PM}_{2.5}$ & 0.139 & 0.55 & 0.53 & 0.003 \\
\hline Lowland rainforest & $\mathrm{Pop}$ density & 0.548 & 0.30 & 0.28 & $<0.001$ \\
\hline
\end{tabular}

Table 5 Predictive models of the relationship of age of mortality and environmental and climatic variables.

\begin{tabular}{|l|l|l|l|l|l|}
\hline Age range & Predictors & Standardized $\beta$ & $\mathrm{R}^{2}$ & Adj. $\mathrm{R}^{2}$ & $p$-value \\
\hline 0 to 17 & $\mathrm{NO}_{2}$ mean & 0.654 & 0.43 & 0.40 & $<0.001$ \\
\hline 18 to 29 & $\mathrm{NO}_{2}$ mean & 0.422 & 0.18 & 0.16 & 0.001 \\
\hline 30 to 49 & Pop. density & 0.306 & 0.28 & 0.27 & 0.004 \\
\hline & $\mathrm{NO}_{2}$ mean & 0.236 & & & \\
\hline 50 to 79 & Elevation & -0.14 & & & \\
\hline & Pop. density & 0.483 & 0.28 & 0.27 & 0.034 \\
\hline$\geq 80$ & Elevation & -0.14 & & & \\
\hline & Pop. density & 0.309 & 0.36 & 0.35 & 0.046 \\
\hline & $\mathrm{NO}_{2}$ mean & 0.258 & & & \\
\hline & $\mathrm{PM}_{2.5}$ & 0.164 & & & \\
\hline & $\begin{array}{l}\text { Solar radiation } \\
\text { mean }\end{array}$ & -0.113 & & & \\
\hline
\end{tabular}

Table 6 Predictive models of the relationship of case fatality rates and environmental and climatic variables. 
medRxiv preprint doi: https://doi.org/10.1101/2020.09.16.20196170; this version posted September 19, 2020. The copyright holder for this preprint (which was not certified by peer review) is the author/funder, who has granted medRxiv a license to display the preprint in perpetuity. All rights reserved. No reuse allowed without permission.

\begin{tabular}{|l|l|l|l|l|l|}
\hline & Predictors & Standardized $\beta$ & $\mathrm{R}^{2}$ & Adj. $\mathrm{R}^{2}$ & $p$-value \\
\hline Peru & Elevation & 0.318 & 0.12 & 0.12 & 0.015 \\
\hline & NDVI & 0.106 & & & \\
\hline Coast & Elevation & 0.281 & 0.08 & 0.06 & 0.022 \\
\hline Sierra & Elevation & 0.303 & 0.12 & 0.11 & 0.029 \\
\hline & NDVI & 0.117 & & & \\
\hline High montane forest & Elevation & 0.466 & 0.22 & 0.20 & $<0.001$ \\
\hline Lowland rainforest & Mean diurnal range & 0.460 & 0.21 & 0.19 & 0.002 \\
\hline
\end{tabular}




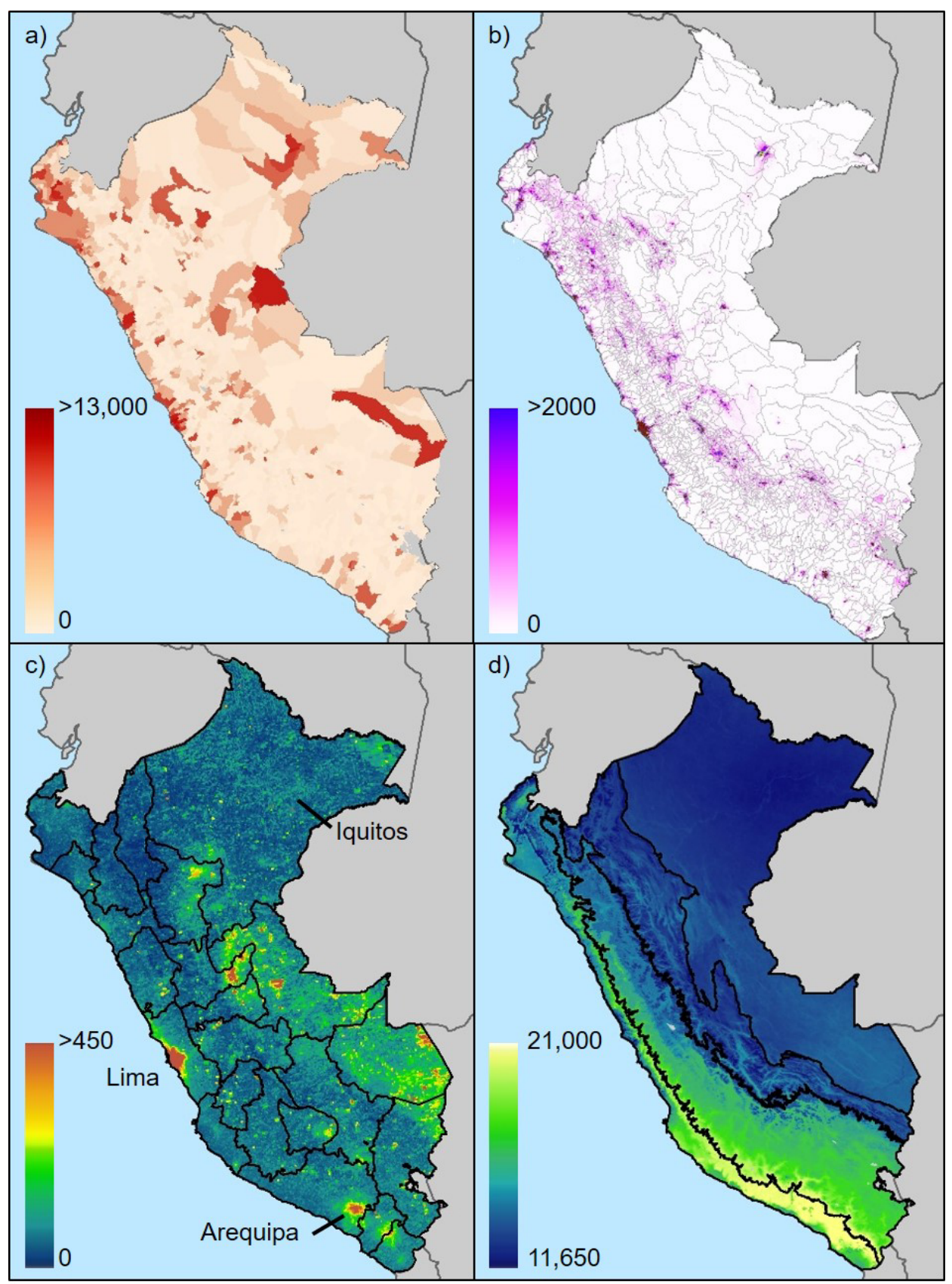

Figure 1 a) Cumulative number of confirmed infected cases per district, b) modeled population density (people $\mathrm{km}^{-2}$ ) for the year 2020, c) maximum tropospheric $\mathrm{NO}_{2}$ density $\left(\mu \mathrm{mol} \mathrm{m}{ }^{-2}\right.$ ) for 2019, and d) mean solar radiation $\left(\mathrm{kJ} \mathrm{m}^{-2} \mathrm{day}^{-1}\right)$. Outlines in a) and b) are district boundaries, while outlines in c) indicate departmental boundaries and d) (left to right) the coast, sierra, high montane forest and lowland rainforest ecozones. 


\begin{tabular}{|c|c|c|c|c|c|}
\hline \multirow[b]{2}{*}{ Variables } & \multicolumn{5}{|c|}{ Mortality } \\
\hline & Infection & CSD & All & Male & Female \\
\hline $\begin{array}{l}\text { Annual mean } \\
\text { temp. }\end{array}$ & $* * *$ & $* *$ & $* * *$ & $* * *$ & $* *$ \\
\hline $\begin{array}{l}\text { Mean diurnal } \\
\text { temp. range }\end{array}$ & $* * *$ & $* * *$ & $* * *$ & $* * *$ & $* * *$ \\
\hline Temp. seasonality & $* * *$ & & $* * *$ & $* * *$ & $* * *$ \\
\hline $\begin{array}{l}\text { Temp. annual } \\
\text { range }\end{array}$ & $* * *$ & $* *$ & $* * *$ & $* * *$ & $* * *$ \\
\hline Annual precip. & $* * *$ & & $* * *$ & $* * *$ & $* * *$ \\
\hline $\begin{array}{l}\text { Precip. of Wettest } \\
\text { Month }\end{array}$ & $* * *$ & & $* * *$ & $* * *$ & $* * *$ \\
\hline Precip. seasonality & & & & & \\
\hline $\begin{array}{l}\text { Precip. of warmest } \\
\text { quarter }\end{array}$ & $* * *$ & & $* * *$ & $* * *$ & $* * *$ \\
\hline $\begin{array}{l}\text { Solar radiation } \\
\text { (mean) }\end{array}$ & $* * *$ & & & & \\
\hline $\begin{array}{l}\text { Solar radiation } \\
\text { (SD) }\end{array}$ & $* * *$ & $* * *$ & $* * *$ & $* * *$ & $* * *$ \\
\hline $\begin{array}{l}\text { Water vapor } \\
\text { pressure (mean) }\end{array}$ & $* * *$ & $* *$ & $* * *$ & $* * *$ & $* * *$ \\
\hline $\begin{array}{l}\text { Water vapor } \\
\text { pressure (SD) }\end{array}$ & $* * *$ & $* *$ & $* * *$ & $* * *$ & $* * *$ \\
\hline $\begin{array}{l}\text { Wind speed } \\
\text { (mean) }\end{array}$ & $* * *$ & & $* * *$ & $* * *$ & $* * *$ \\
\hline Wind speed (SD) & & $* *$ & $* * *$ & $* *$ & $* * *$ \\
\hline Elevation & $* * *$ & $* * *$ & $* * *$ & $* * *$ & $* * *$ \\
\hline NDVI mean & $* * *$ & $*$ & $* * *$ & $* * *$ & $* * *$ \\
\hline $\mathrm{PM}_{2.5}$ mean & $* * *$ & $* *$ & $* * *$ & $* * *$ & $* * *$ \\
\hline $\begin{array}{l}\text { Tropospheric } \mathrm{NO}_{2} \\
\text { mean }\end{array}$ & $* * *$ & $* * *$ & $* * *$ & $* * *$ & $* * *$ \\
\hline $\begin{array}{l}\text { Tropospheric } \mathrm{NO}_{2} \\
\text { max. }\end{array}$ & $* * *$ & $* * *$ & $* * *$ & $* * *$ & $* * *$ \\
\hline Pop. Density & $* * *$ & $* * *$ & $* * *$ & $* * *$ & $* * *$ \\
\hline
\end{tabular}

Figure 2 Spearman's correlation between climatic and environmental factors and the cumulative cases of infection, case-fatality rate (CFR) and mortality. The color gradient indicates correlation coefficients, where darker red indicates a correlation approaching 1 and a darker blue indicates a correlation approaching -1 . Statistical significance were $* \mathrm{p}<0.05,{ }^{* *} \mathrm{p}<0.01$, and $* * * \mathrm{p}<0.001$.

\section{ON-LINE DEPOSITORY}




\section{Victor J. Samillan ${ }^{1 \#}$ Diana Flores ${ }^{2}$ Eduardo Rojas $^{3}$ Brian R. Zutta ${ }^{4 \#}$}

\section{Ecozones}

For the purposes of our study, the ecozones originally categories as "selva alta accessible" (accessible high jungle) and "selva alta dificil" (difficult high jungle) were merged to high montane forest ecozone. Similarly, the hydromorphic zone was merged with the lowland rainforest ecozone.

\section{Climate data}

A set of climate metrics were obtained from WorldClim version 2.1 (Fick \& Hijmans, 2017). These metrics are derived from monthly climatologies, which include monthly temperature, rainfall, wind speed, and solar radiation. These monthly climatologies were developed using a series of global and country networks of weather stations and represent a historical baseline from the years 1979 to 2000 . The data is interpolated into monthly climate metrics at a $1 \mathrm{~km}$ spatial resolution and at the global scale. Eleven temperature and eight precipitation metrics were used, which represent measures of annual means and seasonality. Three wind speed and three solar radiation metrics were also used, which include annual mean, annual standard deviation and annual maximum. The total number of climate layers initially available for this study was 29 before they were reduced to avoid collinearity

\section{Environmental data}

Environmental data was obtained from a variety of satellite sensors that detect environmental variables, including elevation, vegetation cover, and air quality. We used the Shuttle Radar Topography Mission (SRTM) digital elevation data at the native $90 \mathrm{~m}$ spatial resolution.

To quantify vegetation cover, we used the MODIS (Moderate Resolution Imaging Spectroradiometer) Terra 16-day NDVI (Normalized Difference Vegetation Index) product to calculate the mean NDVI value over Peru for the year 2019. NDVI is a widely used spectral index that is highly correlated with vegetation and has a range of value from +1 to -1 , where values close to +1 , indicate dense green vegetation, and values close to 0 indicate barren ground or artificial surfaces. NDVI values of Peruvian rainforests or well irrigated agricultural plants would approach a value of 1 , while cities with mostly artificial surfaces and very few urban trees or gardens would have an average value closer to zero.

We infer long term exposure to air pollution through the metrics of two health-relevant pollutants, which include particulate matter at $2.5 \mu \mathrm{m}$ (PM 2.5) and nitrogen dioxide $\left(\mathrm{NO}_{2}\right)$. Mean PM 2.5 (dust column mass density in $\mathrm{kg} \mathrm{m}^{-2}$ ) was obtained from the MERRA-2 (ModernEra Retrospective analysis for Research and Applications version 2) using the the Goddard Earth Observing System Model, Version 5 (GEOS-5) with its Atmospheric Data Assimilation System (ADAS), version 5.12.4, which was available through NASA's Giovanni application (v. 4.34; https://giovanni.gsfc.nasa.gov/). We used the native spatial resolution of $0.5 \times$ $0.625^{\circ}$ (approximately $3,850 \mathrm{~km}^{2}$ ) and the annual mean for the year 2019. Tropospheric $\mathrm{NO}_{2}$ density $\left(\mu \mathrm{mol} \mathrm{m}{ }^{-2}\right.$ ) for 2019 was obtained from the Copernicus Sentinel-5P satellite, which holds the TROPOspheric Monitoring Instrument (TROPOMI). We used the native spatial resolution of $7 \mathrm{~km}$ and metrics of annual mean and maximum value for the year 2019, which was obtained through Google Earth Engine.

The total number of environmental data layers assessed for this study was 6 , which were assessed for collinearity through Superman's Rho correlation and stepwise linear regression collinearity diagnostics. 
medRxiv preprint doi: https://doi.org/10.1101/2020.09.16.20196170; this version posted September 19, 2020. The copyright holder for this preprint (which was not certified by peer review) is the author/funder, who has granted medRxiv a license to display the preprint in perpetuity.

All rights reserved. No reuse allowed without permission. 


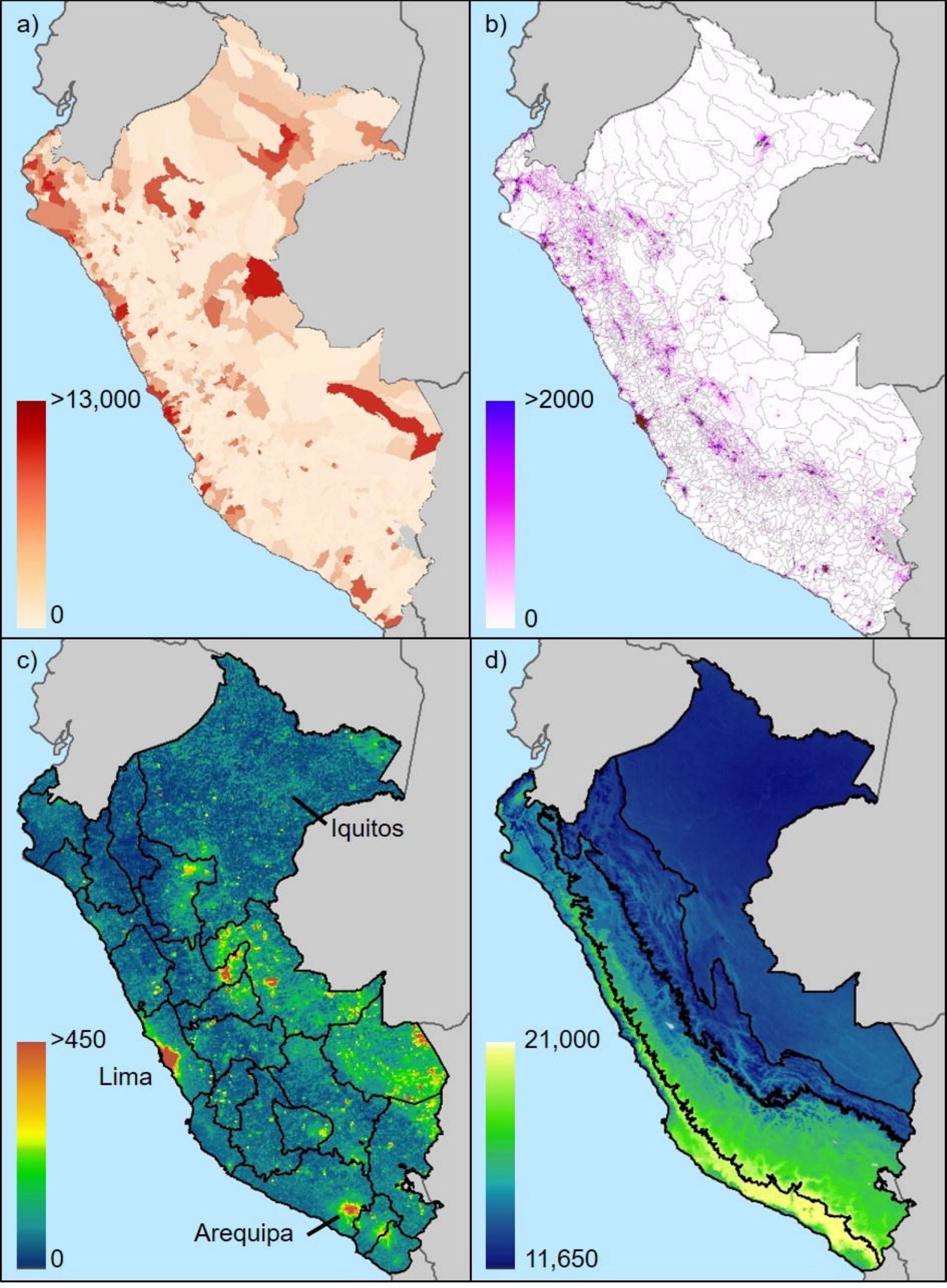




\begin{tabular}{|c|c|c|c|c|c|c|}
\hline \multirow[b]{2}{*}{ Variables } & \multicolumn{5}{|c|}{ Mortality } & \\
\hline & Infection & CSD & All & Male & Female & \\
\hline $\begin{array}{l}\text { Annual mean } \\
\text { temp. }\end{array}$ & $* * *$ & ** & $* * *$ & $* * *$ & $* *$ & \\
\hline $\begin{array}{l}\text { Mean diurnal } \\
\text { temp. range }\end{array}$ & $* * *$ & $* * *$ & $* * *$ & $* * *$ & $* * *$ & \\
\hline Temp. seasonality & $* * *$ & & $* * *$ & $* * *$ & $* * *$ & \\
\hline $\begin{array}{l}\text { Temp. annual } \\
\text { range }\end{array}$ & $* * *$ & ** & $* * *$ & $* * *$ & $* * *$ & \\
\hline Annual precip. & $* * *$ & & $* * *$ & $* * *$ & $* * *$ & \\
\hline $\begin{array}{l}\text { Precip. of Wettest } \\
\text { Month }\end{array}$ & $* * *$ & & $* * *$ & $* * *$ & $* * *$ & \\
\hline Precip. seasonality & & & & & & \\
\hline $\begin{array}{l}\text { Precip. of warmest } \\
\text { quarter }\end{array}$ & $* * *$ & & $* * *$ & $* * *$ & $* * *$ & \\
\hline $\begin{array}{l}\text { Solar radiation } \\
\text { (mean) }\end{array}$ & $* * *$ & & & & & \\
\hline $\begin{array}{l}\text { Solar radiation } \\
\text { (SD) }\end{array}$ & $* * *$ & $* * *$ & $* * *$ & $* * *$ & $* * *$ & \\
\hline $\begin{array}{l}\text { Water vapor } \\
\text { pressure (mean) }\end{array}$ & $* * *$ & $* *$ & $* * *$ & $* * *$ & $* * *$ & \\
\hline $\begin{array}{l}\text { Water vapor } \\
\text { pressure (SD) }\end{array}$ & $* * *$ & ** & $* * *$ & $* * *$ & $* * *$ & 1 \\
\hline $\begin{array}{l}\text { Wind speed } \\
\text { (mean) }\end{array}$ & $* * *$ & & $* * *$ & $* * *$ & $* * *$ & \\
\hline Wind speed (SD) & & $* *$ & $* * *$ & $* *$ & $* * *$ & 0.5 \\
\hline Elevation & $* * *$ & $* * *$ & $* * *$ & $* * *$ & $* * *$ & \\
\hline NDVI mean & $* * *$ & * & $* * *$ & $* * *$ & $* * *$ & 0 \\
\hline $\mathrm{PM}_{2.5}$ mean & $* * *$ & $* *$ & $* * *$ & $* * *$ & $* * *$ & \\
\hline $\begin{array}{l}\text { Tropospheric } \mathrm{NO}_{2} \\
\text { mean }\end{array}$ & $* * *$ & $* * *$ & $* * *$ & $* * *$ & $* * *$ & -0.5 \\
\hline $\begin{array}{l}\text { Tropospheric } \mathrm{NO}_{2} \\
\text { max. }\end{array}$ & $* * *$ & $* * *$ & $* * *$ & $* * *$ & $* * *$ & \\
\hline Pop. Density & $* * *$ & $* * *$ & $* * *$ & $* * *$ & $* * *$ & -1 \\
\hline
\end{tabular}

